\title{
Spatial structure counts: the relevance of regional labour-market conditions for educational transitions to vocational training
}

\author{
Katarina Weßling ${ }^{*}$ (D), Andreas Hartung and Steffen Hillmert
}

\author{
*Correspondence: \\ katarina.wessling@uni-tuebingen.de \\ Department of Sociology, \\ University of Tuebingen, \\ Wilhelmstraße 36, \\ 72074 Tuebingen, Germany
}

\begin{abstract}
Regional context conditions can have a crucial impact on school-to-work transitions and subsequently individual life chances. This paper aims to develop an approach to analyse the spatial references of regional socio-economic contextual settings young adults are embedded in. We apply this approach to assess the impact of regional unemployment on the transition from lower or intermediate compulsory schooling to vocational education and training (VET) in Germany. We use data from the German Socio-Economic Panel Study (GSOEP) and merge these with administrative time series data on NUTS 3-regions level. We attach geocodes to the administrative districts to allow for a flexible operationalisation of the spatial reference of regional socioeconomic contextual settings. Our results indicate, first, a negative relation between regional unemployment and the chances of entering vocational training in the dual system. Second, the effects of unemployment on adolescents' transition chances have a specific spatial structure: The labour-market situation in the respondent's district of residence moderates the relation between the labour-market situation in surrounding districts and the school graduates' chances of entering dual training.
\end{abstract}

Keywords: School-to-work transitions, Vocational education and training (VET), Dual system, Regional labour-market conditions, Spatial patterns, GSOEP, Linking micro- and macro-level data

\section{Background}

Acquiring vocational qualifications is a central determinant for individual life chances in many contemporary societies. Vocational training opportunities are provided and shaped by the structure of the specific education and training system. In research on school-to-work transitions a great deal of attention is given to questions that deal with differential chances of entering vocational education or training (VET). It is well known that social contexts in which individuals are embedded have a strong impact on educational decision-making behaviour and actual transition chances. Contexts that are known to have an impact in these terms are families, class-rooms or schools, but educational differences between individuals even exist when these conditions are comparable. An additional source of explanation for these disparities can be varying regional context conditions representing, e.g., the local labour-market situation. This paper focuses on the relevance of regional labour-market conditions for transitions to vocational training.

(c) 2015 Weßling et al. This article is distributed under the terms of the Creative Commons Attribution 4.0 International License (http://creativecommons.org/licenses/by/4.0/), which permits unrestricted use, distribution, and reproduction in any medium, provided you give appropriate credit to the original author(s) and the source, provide a link to the Creative Commons license, and indicate if changes were made. 
We address two main conceptual issues and illustrate them empirically for the case of Germany: First, previous research argues that high unemployment discourages young people from entering the labour market but encourages them to extend their general educational career instead. It is, so far, an open question if this assumption holds true for transitions from school to vocational training. In countries with well-developed apprenticeship programmes and a strong linkage between training and labour market (e.g., Germany, the Netherlands, Switzerland) this question is highly relevant. Second, we focus on conceptualising local labour markets in terms of their spatial extension. The crucial question here is: Where is the regional labour market located that is assumed to influence young adults chances of obtaining a training position?

The paper is structured as follows: In the second section post-compulsory education and training alternatives in Germany are illustrated. In section three we provide a literature review focusing on disparities in education and training chances and the impact of local labour markets. Subsequently, we describe our theoretical model that combines a flexible spatial concept with models on educational transition chances. We further explicate how we prepare aggregated time-series data on labour-market conditions in administrative districts and neighbouring and surrounding districts. The time-series data is merged with individual panel data of the German Socio-Economic Panel Study (GSOEP). We then discuss descriptive findings and analytical results. In our conclusion we draw attention to practical implications following our results and to potentials for further research.

\section{Education and training alternatives after compulsory schooling}

The German VET-system offers a well-developed apprenticeship programme with strongly emphasising on-the-job experiences in the so called dual system. The dual training is the most important track for obtaining an occupational qualification in Germany: In 2011, 57 \% of an age cohort started training in the dual system (Statistisches Bundesamt 2013, 8). Beyond that, the VET-system offers school-based training programmes in specific occupations. These two full-qualifying training programmes usually last for 2-3 years and lead to specific occupational qualifications. In addition to the full-qualifying opportunities, the German VET-system offers several preparatory tracks (BMBF 2012, 40). These courses are aimed to bridge the gap for unsuccessful applicants to improve their level of educational qualification. Beyond vocational training opportunities, all school leavers-except those with the highest possible school-leaving certificate (Abitur) - have the opportunity to attend further general schooling. Another option is to enter the labour market directly without any vocational qualification. Due to the strongly developed VET-system and the obligation to stay in education up to a certain age this decision is rather unlikely in Germany.

Chances of entering one of the possible educational alternatives subsequent to general compulsory schooling vary considerably depending on the previously attended school track. In principle, all school leavers (even dropouts) have the possibility to enter dual training. In the dual system, employers decide the recruiting of apprentices. Hence, access to the dual system results from a bilateral matching process between applicant and employer. With respect to the recruitment mechanisms, entering an apprenticeship is therefore comparable to labour market entry. Compared to the dual system, full-time 
school-based vocational training is far more subject to institutional specificities: An intermediate school degree often represents the minimum requirement (Dobischat 2010). Due to the strong ties between labour market and dual training, the dual training market and subsequently the entire VET-system is strongly linked to socio-economic characteristics and developments.

\section{Training prospects and regional socio-economic conditions}

Previous research on transitions after compulsory schooling made the following observations: Chances in post-school transitions, especially entering a vocational training track in the dual system, differ strongly according to previous school achievements. But gender differences can also be found along with disparities due to the social and ethnic origin (e.g., BMBF 2012; Bernardi and Requena 2010). These effects are not separate, but are mutually linked to one another: Differences in previous school achievements are strongly influenced by social background (e.g., Beicht 2012; Müller and Haun 1994). These social disparities in the process of educational attainment are usually explained by differences in the parental social status. On the other hand, individual chances of entering vocational training differ considerably due to the familial background even when controlling for previous education (Hupka-Brunner et al. 2010), which-following status reproduction assumptions-can be interpreted as secondary effect (Boudon 1974) and a direct influence of social background on educational decisions in the later educational career (Hillmert and Weßling 2014). Beyond that, immigrant youth are to a greater extend concerned with aspects of social origin, especially the large group of migrant labourers in Germany has a below average educational level. Further independent impacts of immigrant background on training chances are caused by an undersupply of social and cultural capital, e.g., lack of language capital or information on the educational system of the host country (e.g., Kalter 2006).

We argue that regional socio-economic conditions contribute-in addition to, but also interacting with the set of individual aspects-to the explanation of inequality in education and training chances. The competitive pressure in search for a vocational training position has increased in recent years, especially for students with no or lower school certificates (Kleinert and Jacob 2012). Focusing on competition draws attention to macro-level factors that determine the demand of vocational training opportunities, e.g., population development, labour-market conditions and economic characteristics of a region.

Research that explicitly links aspects of education and regional diversity draws upon a long tradition of descriptive studies. The main focus here lies on the infrastructural concentration of educational institutions on the one hand and dimensions of socio-structural composition of the population on the other (Ditton 2008; Eirmbter 1977; Meulemann and Weishaupt 1976). A remarkable body of international economic research has dealt with the role of labour-market expectancies for an investment in (further) general education. In empirical terms, these studies focus on the labour market entry. The relevance of regional labour-market conditions for an investment in vocational education and training in countries with a strongly developed VET-system remains an open question. In theoretical terms, previous studies argue that investments in education depend on the expected returns to education. These expectancies are 
shaped by the individual perception of labour-market conditions (Carmeci and Chies 2002; Peraita and Pastor 2000; Betts and McFarland 1995). A central argument for a positive relation between unemployment and the enrolment in further education is that high unemployment tends to discourage young adults from quickly entering the labour market (discouraged worker effect; e.g., Micklewright et al. 1990; Raffe and Willms 1989). In that sense, higher education is used as an 'escape' from unemployment. This relationship also applies when economic conditions improve: Young adults lack incentives to stay in the general school system and are more likely to enter the labour market (warehouse hypothesis; e.g., Walters 1984; Grubb and Lazerson 1982). The majority of studies put forward arguments for a positive impact of (local) unemployment on further general education, empirical evidence is less clear. Studies that make use of aggregated data find a significant impact of local unemployment on participation rates in further general schooling. These studies mainly confirm the assumption of a positive effect (Clark 2011). Research using aggregate data that directly focuses on vocational training provides empirical evidence for regional differences in participation rates in vocational training depending on regional unemployment and cohort size in Germany (Heineck et al. 2011). Differences in participation rates are particularly visible between East and West Germany (Ulrich 2013). Furthermore, cyclical developments and demographic change have direct impacts on the number of apprenticeship programs offered by firms (Muehlemann, Wolter and Wüest 2009, Wolter and Ryan 2011).

However, empirical evidence that combines individual micro-data with macroinformation is less frequent and more ambiguous: Some studies fail to find any influence (Micklewright, Pearson, and Smith 1990), while others find a weak impact of local labour-market conditions on post-secondary participation (Tumino 2013; Meschi, Swaffield, and Vignoles 2011; Rice 1999). Some studies that find an impact also show that the effect of unemployment differs with respect to individual characteristics. Especially low-qualified male graduates are positively influenced to enrol in further education when unemployment is high (Pissarides 1981; Rice 1999; Meschi, Swaffield, and Vignoles 2011). A major problem in these studies is that regional labour-market conditions are measured on different levels of aggregation-counties, districts or federal states-which makes interpretations and comparisons difficult. So far, it is an only partly resolved issue in social research to adequately conceptualise and determine the spatial extension of contextual settings individuals are embedded in (Weller 2008). This paper aims to contribute to the ongoing discussions in two ways: First, we analyse the impact of local labour-market conditions for transitions chances to vocational training. Second, by means of spatial analysis techniques our purpose is to assess the geographic extension of this local labour market.

\section{Theoretical considerations}

The transition to training is a two-sided process depending on the graduates' educational decisions on the one hand and on the demand for trainees on the training market on the other. With respect to educational decisions we understand the processes of educational attainment as an accumulated result of educational decisions (Mare 1980; Boudon 1974), being based on the evaluation of three crucial factors: costs, utility and (perceived) success probability. This theoretical perspective integrates the motive of status 
maintenance as a cost-benefit component into a more general framework of rational decision making. Educational inequality with respect to the parents' social status results, to a significant degree, from the wish of retaining this status over generations (e.g., Breen and Goldthorpe 1997). The cost-benefit calculation varies by social class origin, so that the subjectively expected utility determines educational decisions and accordant social inequalities. Aggregated socio-economic characteristics, such as regional unemployment, can additionally affect the perception of costs and benefits (Card and Lemieux 2001). Contextual settings such as local labour-market conditions supplement institutional characteristics that can be understood as a framework defining and limiting the scope of action (Hillmert 2004). Experiencing poor economic conditions diminishes the expected chances of successfully entering the labour market-in our case the training market-and hence the subjectively anticipated benefits of leaving general education.

Independent of the graduates' preferences, the availability of training places may be influenced by the general labour-market situation. Economic fluctuations can have two potential influences on employers' decisions. On the one hand employers might be reluctant to invest in training as their need for additional skilled workers is uncertain and budgets tend to be tight. In times of economic downturns recruitment costs sink, so that even if firms train apprentices instead of employing skilled workers, the latter become relatively more attractive to employers. In both instances, poor labour-market conditions lead to a decreasing demand for apprentices (Wolter and Ryan 2011). These effects primarily refer to economic developments over time but they can in part be assumed to hold true for regional differences, too. In addition to that previous research that directly refers to regional differences could show that firms are less willing to train in more isolated and poor labour market regions (Muehlemann and Wolter 2011).

To capture this two-folded transition process, we define two mechanisms through which regional unemployment might have an effect on young adults' chances of entering vocational training:

(1) Opportunities: Effective chances of beginning a dual training after compulsory schooling are structured by labour-market conditions. Poor labour-market conditions can entail shortages in the demand for trainees. In addition, the number of applicants in an age cohort which is primarily a function of demographic development constitutes another determinant of competition on the training market.

(2) Preferences: Individual perception of unemployment influences the evaluation of educational and occupational chances and shapes the perceived returns to education.

Although it is difficult to empirically differentiate between the two mechanisms when only analysing the outcome of an educational transitions, it seems crucial to theoretically distinguish between them as the conceptual differentiation of effects might be one explanation for the contradicting results on the impact of regional unemployment found in the literature.

\section{Analytical concept and hypotheses}

Previous research argues that high unemployment discourages young adults from quickly entering the labour market. By transferring the discussion on the impact of local 
unemployment on returns to education to an institutional context with a well-developed training system (e.g., Germany, The Netherlands, Switzerland) we expect-regarding this training system-the following general relationship between regional unemployment and post-compulsory educational transitions:

Hypothesis 1a: The higher the level of unemployment in the relevant regional unit(s), the lower the individual chance of entering a vocational training in the dual system compared to other educational alternatives (staying in school, vocational preparation or school-based vocational training).

Regarding the two outlined mechanisms we assume that effects of regional unemployment point in the same direction: The effect for the demand for apprentices refers to the availability of dual training. High unemployment should lead to limitations for employers and subsequently to a shortage in training opportunities. The second effect of unemployment refers to the individual perception of unemployment. High unemployment discourages graduates from starting a dual training and rather keeps students in more general tracks of education (general school or school-based vocational training). Beyond a general hypothesis on the effective direction, we assume that the impact of regional unemployment is different for different social groups:

Hypothesis 1b: This negative impact of unemployment is higher for drop-outs and school graduates with a lower secondary (Hauptschule) degree compared with an intermediate secondary (Realschule) certificate.

With higher unemployment and fewer training places the competitive pressure in search for training is particularly high for students with no or lower school certificates (Kleinert and Jacob 2012; Hillmert 2001). Therefore, we argue that their chances decrease when higher unemployment is present.

The main aim of this paper is to capture the spatial extension of the impact of these regional labour-market conditions on training chances. It is a typical observation in spatial context research that political borders are often not sufficient to define relevant areas (Hillmert 2015). In particular, research on the modifiable area unit problem (MAUP) has shown that the definition of areas affects the results, even when the same variables are analysed (Andersson and Malmberg 2014; Kwan 2012; Fotheringham and Wong 1991). As previous macro-level research suggest that regional training and labour markets differ in size, extension and accessibility, it is appropriate to include spatial measurements such as contiguities as well as commuting or travel time distances (e.g., Sforzi 2012; Heineck et al. 2011; Eckey et al. 2007). Muehlemann and Wolter (2011) for example find evidence for the influence of regional labour-market conditions on the willingness of employers to train only when regional labour markets are conceptualised on the basis of travel time, but not when taking political borders into account. Therefore, we integrate concepts of spatial analysis (e.g., Elhorst 2014; Anselin 1995) into a conventional analytical model. We try to overcome the fixed limitations of administrative boundaries by 
constructing concentric rings of neighbouring territorial units of NUTS 3-regions ${ }^{1}$ (administrative districts (Kreise)). To capture the spatial extension of a labour-market region and to analyse where unemployment has an influence on the transition to training, we make use of the administrative district where young adults live, as well as the first-order and the second-order neighbouring districts. The spatial units are taken into account separately (see Fig. 1). The neighbouring rings are identified by calculating contiguity matrices (e.g., Drukker, Pruchar, and Raciborski 2001) for the 412 (referring to the year 2009) NUTS 3-regions on the basis of geo-referred area codes.

The concentric ring model is considered particularly appropriate because it partly rules out the problem of multicollinearity by calculating the context indicators for the surrounding spatial districts, while excluding the already controlled contexts of lower order. This concept enables one to specify the overall effect of the regional contexts as an additive or a mediating effect. For the latter, interaction effects or effect thresholds have to be specified.

Hypothesis 2: The impact of unemployment on chances of entering dual training is higher for the regional unit of residence and the direct neighbouring regional units compared with the impact of the second-order neighbouring regional units.

Regarding the spatial extension of the effect of unemployment it can be argued that the supply of training positions increases continuously: The larger the spatial ring, the more training opportunities available. Focusing on the individual demand for training the accessibility plays an important role. This refers to the spatial structure of job or training search behaviour and commuting distances. From previous research on job search behaviour it is known that workers are willing to accept lower wages in order to avoid additional travel distances (Manning and Petrongolo 2013; Rouwendal 1999). Daily work-related commuting distances in Germany vary according to regional differences, ranging between 15 and over 30 kilometres on average and are steadily increasing (Einig and Pütz 2007). Previous research shows that regional disparities in the demand for trainees, corresponds with the commuting activity of young adults (Bogai, Seibert, and Wiethölter 2008). In general, it can be assumed that the commuting radius of underaged workers is more restricted because they need public transport systems. By calculating distance matrices from the centre of every administrative district to the centre of the neighbouring districts we find that the distances are on average about 34 kilometres. Due to the limitation of the search radius by the reachability of training places the demand for training should be higher in closer ranges. Regarding the spatial structure of the impact of local unemployment on training chances we expect the following:

Hypothesis 3: The impact of unemployment in the first- and second-order neighbouring regional units on the chance of entering training in the dual system is higher when unemployment is high in the regional unit of residence.

We argue that the neighbouring rings are of particular relevance when training chances are low in the home district because young adults in search for a training

\footnotetext{
${ }^{1}$ German administrative districts (Kreise/Landkreise) are an intermediate level of administrative units between the level of states (Länder) and the level of municipal districts (Gemeinden). They correspond to the administrative units of NUTS 3 (Nomenclature of Territorial Units for Statistics). In 2011, the total number of districts was 402, of which 295 were rural areas (Landkreise) and 107 were independent cities (kreisfreie Städte). The number of inhabitants varies greatly between approximately 50,000 (Landkreis Lüchow-Dannenberg) up to 1.1 mio (Region Hannover) for rural areas (kreisfreie Städte) and between 33,800 (Zweibrücken) and 3.5 mio (Berlin) for independent cities (kreisfreie Städte).
} 


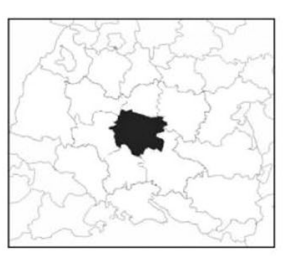

Administrative districts
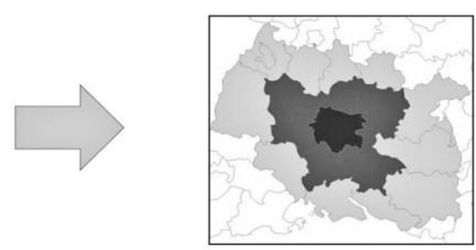

Administrative district + neighbouring districts $1^{\text {st }}$ and $2^{\text {nd }}$ order

Fig. 1 Admininstrative districts and 1st and 2nd order neighbouring districts

position focus on areas further afield (i.e. the first and second neighbouring rings) when unemployment is high and subsequently chances of entering dual training are low in the close range. We test this hypothesis by introducing interaction terms between the unemployment rates of the different spatial units.

\section{Data and methods}

The individual-level data is from the German Socio Economic Panel (GSOEP) ${ }^{2}$. The GSOEP is a household panel that has been carried out since 1984. Since 2000 young adults who live in households that are part of the survey are interviewed regarding their school career and career plans as a part of a special youth questionnaire. They are first interviewed at the age of 16 or 17 (Schupp and Frühling 2007, 149ff.). For the years 20002012, individual-level data is available for 4190 young adults containing information on their place of residence which enables us to merge contextual information about the local labour-market situation to the data set (Additional file 1: Appendix Fig. S1). The number of cases is reduced to 2778 because young adults who are still in school at the time of the interview are excluded. School graduates with the highest school leaving certificate ( $A b i-$ tur) are not included in the sample because the focus of this paper lies on educational alternatives after compulsory schooling. This includes the opportunity of further general school attendance as an alternative to an apprenticeship in the dual system. Following our research hypotheses we argue that attending further schooling represents an opportunity to avoid or postpone the labour market entry in a poor labour-market region. However, the decision situation changes fundamentally once the highest school-leaving certificate is obtained. Further schooling does no longer represent an educational option for young adults with Abitur. A more practical argument deals with regional mobility behaviour: The majority of lower- and intermediate secondary school graduates is still underage and it is likely that they stay in the local area where they obtained their school leaving certificate, a fact that reduces the complexity of our model. Subsequently the number of cases is reduced to 2778. The sample is also adjusted with respect to young adults who answered the GSOEP youth questionnaire but not the yearly conducted individual questionnaire and vice versa. Information from both questionnaires is necessary to make use of the panel information. Eventually cases with missing information in the independent variables (Additional file 2: Appendix Table S1) are excluded.

2144 individuals ( 3970 person years) are available for our analysis. The potential educational alternatives (see Fig. 2) are summarised into a binary variable that differentiates

${ }^{2}$ Socio-Economic Panel Study (SOEP), 1984-2012, version 29, doi:10.5684/soep.v29. 


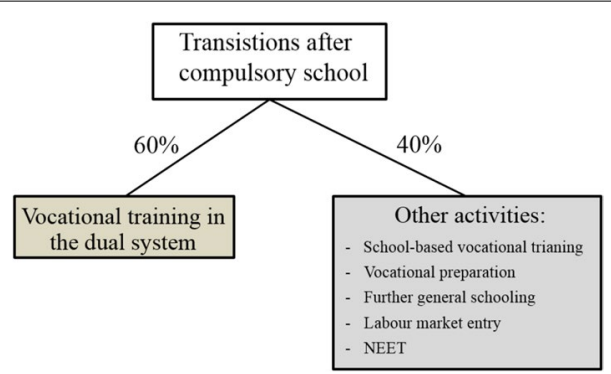

Fig. 2 Binary outcome variable: Observed transitions from lower and intermediate schooling within the first 3 years after leaving school. Data: GSOEP, 2012

between entering vocational training in the dual system within the first 3 years after leaving school versus the other educational alternatives. We choose this operationalisation because the impact of socio-economic conditions is assumed to be particularly important for the chances of starting vocational education in the dual training track due to close linkage to the labour market.

Important independent variables on the individual level are school-leaving certificate, gender as well as parents' school qualification and parents' vocational qualification. Immigrant background is also included in the analyses.

The context data originates from the Federal Employment Agency and the Federal Statistical Office, it allows considering labour-market information on the level of NUTS 3 regions (administrative districts (Kreise)) from 1999 onwards. Districts are administrative units that consist either of an association of small municipalities or of one larger district town. They vary considerably with regard to the number of inhabitants and their spatial extent, which is why age-specific population is included in our analysis. This measure of population is not only integrated so to capture the differences in population between the districts but also to illustrate the competitive situation on the training market.

The administrative districts can be matched to survey data by district codes. These identifiers change over time due to reforms within the administrative districts (Weßling and Wicht 2015). With an adjusted time series format a data set of unemployment rates and age-specific population from 1999 to 2011 on the level of districts is constructed.

A graphical representation of unemployment rates in administrative districts can be seen in Fig. 3. Unemployment rates are displayed in six groups. The illustration shows that overall labour-market conditions were relatively tense during the mid-2000 s and eased only in the last years of the observation period. We aim to analyse the impact that these spatial patterns of unemployment have on the transition from school to training.

As the GSOEP provides only yearly observations and the beginning of vocational training courses is institutionally predefined to take place once a year (in September), we apply a discrete-time survival analysis (Yamaguchi 1991; Allison 1982). Discrete-time survival models treat time not as a continuous variable, but as being divided into discrete units. We analyse transitions using binary logistic regression, focusing on the first 3 years after leaving lower or intermediate secondary school. The model estimates the probability $h_{j}$ of entering dual training at a discrete point in time $(t)$. Unlike in a crosssectional logit model the discrete time survival model contains a baseline variable $\beta_{0}(t)$ 


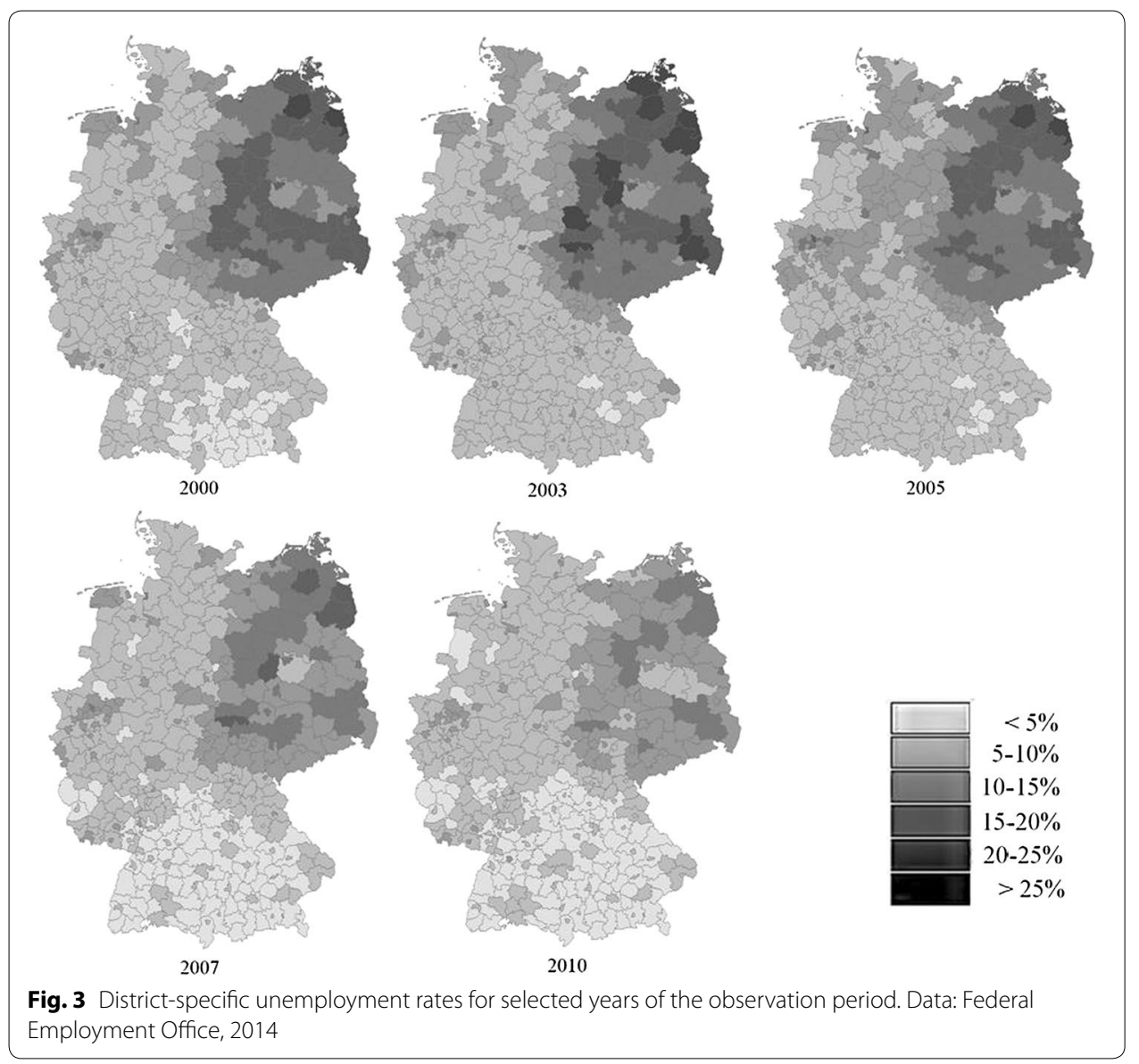

for the observed time points. Our observation period starts with the year when general schooling ends for the first time and ends after 3 years. The most important independent variables are the unemployment rate in the home district at the time when the individual graduates from general compulsory schooling $\left(\beta_{a} x_{j}(t)\right)$, the first-order neighbouring $\left(\beta_{b} x_{j}(t)\right)$ districts and the second-order neighbouring districts $\left(\beta_{c} x_{j}(t)\right)$. We include several control variables-e.g. school leaving certificate $\left(\beta_{z} x_{j}(t)\right)$-in the model.

$$
\begin{aligned}
\operatorname{logit}\left[h_{j}(t)\right]=\log \left[\frac{h_{j}(t)}{1-h_{j}(t)}\right]= & \beta_{0}(t)+\beta_{a} x_{j}(t)+\beta_{b} x_{j}(t)+\beta_{c} x_{j}(t)+\cdots+\beta_{z} x_{j}(t) \\
& +\beta_{a} x_{j}(t) * \beta_{b} x_{j}(t) \\
& +\beta_{a} x_{j}(t) * \beta_{b} x_{j}(t) * \beta_{c} x_{j}(t) \\
& +\beta_{a} x_{j}(t) * \beta_{z} x_{j}(t)+\beta_{b} x_{j}(t) * \beta_{z} x_{j}(t) \\
& +\beta_{a} x_{j}(t) * \beta_{b} x_{j}(t) * \beta_{z} x_{j}(t)
\end{aligned}
$$

A central component of our models are interaction terms: In addition to the additive effects of unemployment, we include interaction terms between unemployment rates in the home and first neighbouring region and a three-way interaction between home, first and second neighbouring regions. The interaction terms between the unemployment rates on the different regional levels represent the assumption that a specific unemployment situation in the home district changes the effects of unemployment in the first- and second-order neighbouring districts on the chance of entering dual training. 
In hypotheses $1 b$ it is assumed that young adults with lower previous school performance are to a larger extent affected by higher unemployment. To test this hypothesis, interactions between the unemployment rates on several regional levels and the school leaving certificates are included. As we observe the individuals repeatedly, the models are calculated with robust standard errors to account for clustering on the individual level. In models with categorical or binary dependent variables, unobserved heterogeneity can be a major problem because the coefficients (and subsequently odds ratios) are not only determined by the relation between the dependent und the independent variables, but also by the variances in the unobserved heterogeneity. This causes problems especially when comparing between different models. As the comparison between models is highly relevant in our analysis, Average Marginal Effects (AMEs) are calculated (cf. Mood 2010) (see Table 1). AMEs can be interpreted as the average change in the probability that dual training will be entered if the independent variable increases by one unit, holding all other independent variables in the model constant. To allow for an adequate interpretation of the interactions effects in the models, we additionally calculate conditional marginal effects and marginal effect plots for continuous predictors (Royston 2013).

\section{Results and discussion}

In model 1 (see Table 1) the socio-economic situation is controlled by the unemployment rate and the age-specific population in the administrative district. Population is measured as the change in the share of 15-18 year-olds between previous and present year. The variable is included to account for population differences between districts but also to capture the age-specific competitive situation. In model 2 and 3 unemployment rates and population in the two surrounding rings of neighbouring districts (see Fig. 1 for illustration) and interactions between unemployment rates on the different spatial levels are included stepwise. In model 4 we calculated interaction effects between unemployment on regional levels and previously attend school tracks.

In the first model we find a highly significant negative effect of unemployment in the home district on the chance of entering dual training. An increase in the unemployment rate in the home district by 1 percentage point decreases the probability of entering an apprenticeship by approximately 1 percent. Also, an increase in the share of age-specific population decreases the training chances of school leavers. These contextual effects exist even when controlling for individual indicators that are known to have an impact on the chances of entering training. This result meets the argument in our first rather general hypothesis: School leavers in regions with higher unemployment have lower chances of finding a position in the dual training system.

When including the average level of unemployment measured in the first-order neighbouring districts (model 2), the effect of unemployment in the home district even increases. The average unemployment rate in the adjacent districts also has a significant negative impact on the probability of entering dual training. Beyond controlling for additional effects of the spatial levels we include interactions between the levels to describe a joint effect of regional unemployment. As a single AME is only valid if the covariates are held constant for all cases, it is not possible to simply sum up the interaction coefficients linearly (Norton et al. 2004). To give a precise interpretation, marginal effect plots are 
Table 1 Discrete time event history model for the transition to vocational training in the dual system after secondary schooling (observed within the first 3 years after school), Data: GSOEP 2012, Federal Labour Office 2014, Federal Statistical Office 2014, own calculations

\begin{tabular}{|c|c|c|c|c|}
\hline & Model1 & Model2 & Model3 & Model4 \\
\hline \multicolumn{5}{|l|}{ Time-specific information } \\
\hline $\begin{array}{l}\text { Baseline1 year of school } \\
\text { leaving (ref. 3rd year after } \\
\text { school) }\end{array}$ & $0.082^{* * *}(0.015)$ & $0.082^{* * *}(0.018)$ & $0.082^{* * *}(0.017)$ & $0.081^{* * *}(0.018)$ \\
\hline $\begin{array}{l}\text { Baseline2 1st year after } \\
\text { school leaving (ref. 3rd } \\
\text { year after school) }\end{array}$ & $0.062^{* *}(0.021)$ & $0.062^{* * *}(0.024)$ & $0.062^{* * *}(0.023)$ & $0.064^{* * *}(0.024)$ \\
\hline $\begin{array}{l}\text { Baseline3 2nd year after } \\
\text { school leaving (ref. } 3 \text { rd } \\
\text { year after school) }\end{array}$ & $0.015(0.035)$ & $0.015(0.039)$ & $0.014(0.039)$ & $0.017(0.044)$ \\
\hline \multicolumn{5}{|c|}{ Unemployment information on regional level (s) } \\
\hline $\begin{array}{l}\text { Unemployment rate } \\
\text { (district) }\end{array}$ & $-0.010^{* * *}(0.002)$ & $-0.016^{* * *}(0.003)$ & $-0.009^{* * *}(0.004)$ & $-0.016^{* * *}(0.005)$ \\
\hline $\begin{array}{l}\text { Average unemployment } \\
\text { (1st neighbour districts) }\end{array}$ & & $-0.008^{* *}(0.004)$ & $-0.017^{* *}(0.002)$ & $-0.013^{* *}(0.004)$ \\
\hline $\begin{array}{l}\text { Average unemployment } \\
\text { (2nd neighbour districts) }\end{array}$ & & & $0.004(0.001)$ & \\
\hline \multicolumn{5}{|c|}{ Age-specific population information on regional levels (s) } \\
\hline $\begin{array}{l}\text { Change in } 15-18 \text { year olds } \\
\text { (district) }\end{array}$ & $-0.007^{* * *}(0.004)$ & $-0.008^{* *}(0.004)$ & $-0.006^{*}(0.004)$ & $-0.007^{*}(0.005)$ \\
\hline $\begin{array}{l}\text { Change in } 15-18 \text { year olds } \\
\text { (1 } 1 \text { st neighbour district) }\end{array}$ & & $-0.004(0.015)$ & $0.001(0.016)$ & $0.004(0.021)$ \\
\hline $\begin{array}{l}\text { Change in } 15-18 \text { year olds } \\
\text { (2nd neighbour district) }\end{array}$ & & & -0.008 & \\
\hline $\begin{array}{l}\text { Year (1999-2006) (ref. } \\
\text { 2007-2011 }\end{array}$ & $-0.019^{* * *}(0.023)$ & $-0.019^{* * *}(0.022)$ & $-0.019^{* * *}(0.022)$ & $-0.017^{* *}(0.022)$ \\
\hline \multicolumn{5}{|l|}{ Personal information } \\
\hline Sex (male) & $0.117^{* * *}(0.016)$ & $0.119 * * *(0.016)$ & $0.114^{* * *}(0.016)$ & $0.114^{* * *}(0.017)$ \\
\hline $\begin{array}{l}\text { Dropout without certif. (ref. } \\
\text { lower sec.) }\end{array}$ & $-0.046^{*}(0.026)$ & $-0.052^{* *}(0.027)$ & $-0.055(0.028)$ & $-0.053(0.028)$ \\
\hline $\begin{array}{l}\text { Intermediate secondary } \\
\text { certif. (ref. lower sec.) }\end{array}$ & $0.108^{* * *}(0.018)$ & $0.107^{* * *}(0.017)$ & $0.108^{* * *}(0.017)$ & $0.109^{* * *}(0.018)$ \\
\hline \multicolumn{5}{|l|}{$\begin{array}{l}\text { Social and ethnic back- } \\
\text { ground information }\end{array}$} \\
\hline $\begin{array}{l}\text { Parents have intermediate } \\
\text { school degree (ref. no/ } \\
\text { lower school degree) }\end{array}$ & $0.068^{* * *}(0.021)$ & $0.073^{* * *}(0.021)$ & $0.078^{* * *}(0.021)$ & $0.073^{* * *}(0.023)$ \\
\hline $\begin{array}{l}\text { Parents have university } \\
\text { entrance diploma (ref. } \\
\text { no/lower school degree) }\end{array}$ & $-0.130^{* * *}(0.022)$ & $-0.129^{* * *}(0.021)$ & $-0.127^{* * *}(0.024)$ & $-0.127^{* * *}(0.025)$ \\
\hline $\begin{array}{l}\text { Parents have vocational } \\
\text { training degree (ref. no } \\
\text { voc. degree) }\end{array}$ & $0.061^{* * *}(0.022)$ & $0.063^{* * *}(0.021)$ & $0.058^{* *}(0.021)$ & $0.060^{* *}(0.022)$ \\
\hline $\begin{array}{l}\text { Parents have university } \\
\text { degree (ref. no voc. } \\
\text { degree) }\end{array}$ & $0.002(0.037)$ & $0.000(0.040)$ & $-0.001(0.041)$ & $-0.000(0.041)$ \\
\hline Immigrant background & $-0.034^{* * *}(0.020)$ & $-0.037^{* *}(0.020)$ & $-0.040^{* *}(0.021)$ & $-0.034^{* *}(0.019)$ \\
\hline \multicolumn{5}{|l|}{ Interaction terms } \\
\hline $\begin{array}{l}\text { Unempl. home district } \\
\text { * Unempl. 1st neighb. } \\
\text { district }\end{array}$ & & $0.001^{* *}(0.000)$ & $0.001^{*}(0.000)$ & $0.001^{* *}(0.000)$ \\
\hline
\end{tabular}


Table 1 continued

\begin{tabular}{|c|c|c|c|c|}
\hline & Model1 & Model2 & Model3 & Model4 \\
\hline $\begin{array}{l}\text { Unempl. home district* } \\
\text { Unempl.1st neighb. }{ }^{*} \\
\text { Unempl. 2nd neighb. } \\
\text { district }\end{array}$ & & & $0.000(0.001)$ & \\
\hline $\begin{array}{l}\text { Unempl. home district * } \\
\text { dropout }\end{array}$ & & & & $-0.002(0.001)$ \\
\hline $\begin{array}{l}\text { Unempl. home district }{ }^{*} \\
\text { intermed. school certif. }\end{array}$ & & & & $0.002(0.002)$ \\
\hline $\begin{array}{l}\text { Unempl. 1st neighb. district } \\
\text { * dropout }\end{array}$ & & & & $0.011(0.014)$ \\
\hline $\begin{array}{l}\text { Unempl. 1st neighb. district } \\
{ }^{*} \text { intermed. school certif. }\end{array}$ & & & & $0.016^{* *}(0.002)$ \\
\hline $\begin{array}{l}\text { Unempl. home district } \\
\text { * Unempl.1st neighb. } \\
\text { district * dropout }^{\text {dist }}\end{array}$ & & & & $0.004(0.022)$ \\
\hline $\begin{array}{l}\text { Unempl. home district } \\
\text { * Unempl.1st neighb. } \\
\text { district * intermed. school } \\
\text { certif. }\end{array}$ & & & & $-0.005^{*}(0.022)$ \\
\hline (Mc fadden's) pseudo $\mathrm{R}^{2}$ & 0.1547 & 0.1571 & 0.1581 & 0.1688 \\
\hline LR & 1726.07 & 1783.76 & 1794.33 & 1810.38 \\
\hline $\mathrm{N}$ person years ( $\mathrm{n}$ persons) & $3.970(2.144)$ & $3970(2144)$ & $3970(2144)$ & $3970(2144)$ \\
\hline
\end{tabular}

Presented are average marginal effects (AMEs); robust standard errors in parentheses

Significance level: ${ }^{*} p<0.1,{ }^{* *} p<0.05,{ }^{* * *} p<0.001$

calculated. Figure 4 is based on model 2 and shows AMEs for the impact of the average unemployment rate in the first neighbouring districts for specific plausible values of the unemployment rate in the home district. We find that a higher unemployment rate in the home region leads to an increase in the effect of the unemployment rate of the first neighbouring region.

The observed interaction effect provides clear evidence for a variation in the search radius for dual training with respect to varying contextual conditions: In line with our third hypothesis we find that the impact of local unemployment in the home district is

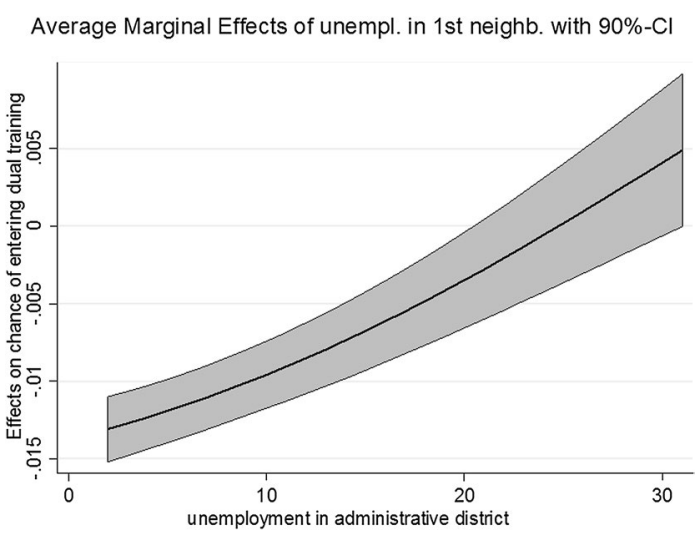

Fig. 4 AMEs (model 2) of unemployment rate in 1st neighbouring districts on the relative chance of entering dual training for specific values of unemployment in home district (with $90 \%$-CIs), Data: GSOEP, Federal Employment Office, Federal Statistical Office 
moderated by the unemployment rate in the neighbouring ring of districts. The higher the unemployment in the home district the more positive the effect of unemployment in the neighbouring districts. The effect of unemployment of the first neighbouring districts becomes insignificant when the unemployment rate in the home district exceeds 20 percent. It can be argued that the observed interaction effect refers to the discouragement of young adults: When unemployment is increasing in their own region, the effect of unemployment in their surroundings is decreasing because educational alternatives-alternatives to an apprenticeship in the dual system-become more and more relevant. In addition, districts with unemployment rates higher than 20 percent-within the observation period between 1999 and 2011-are found exclusively in East-Germany. Due to a low population density these districts are often larger than districts in WestGermany. In these large and rather rural districts with high rates of unemployment the commuting distances can be considered very large, so that, again, rather than finding a training position in the home district young adults opt for other educational alternatives, e.g., school-based vocational training, or further general schooling.

In a next step controls for unemployment in the second-order neighbouring district and a three-way interaction between unemployment in home district and first and second neighbouring ring are included in model 3 to further explore the spatial structure of the unemployment effect. This specification represents the idea of a stepwise extension of the search radius for a training position when the conditions in the close-range area are poor. While results for the home, the first neighbouring districts and the interaction between them remain almost unchanged compared with model 2, we find that the second neighbouring level does not provide significant results (Fig. 5). Changes in the unemployment rate in home or first-order neighbouring districts do not impact the influence of unemployment in the second-order neighbouring districts on the relative chance of entering dual training. The conditional effects are almost zero and not significant. The spatial extension that impacts on the transition chances seems to be on average limited to the home and the direct neighbouring districts. Unemployment in further remote areas has no impact on the transition to training.

Beyond unemployment effects we find negative effects of the population variable for the home district. We argue that an increasing number of young adults of the same age increases the competitive pressure and decreases training chances. Also, we find significant effect for the time variable. This can be interpreted as additional indirect evidence for the importance of the macro-economic situation for individual chances of entering training. One explanation for the time effect is the general relaxation of the labour and training market in recent years (see Fig. 3). These cyclical trends lead to an increasing total net supply of training positions (BMBF 2012). The time effect remains significant even when controlling for unemployment on several levels, suggesting that there might be more indicators than just regional unemployment as predictors for the economic situation.

With respect to the individual control variables the findings are consistent with previous research: Chances of entering dual training are considerably higher for graduates with an intermediate certificate compared with a lower secondary certificate. Dropouts have the lowest chances of entering an apprenticeship programme. We find that school leavers of immigrant origin have lower chances of entering dual training. In line with 

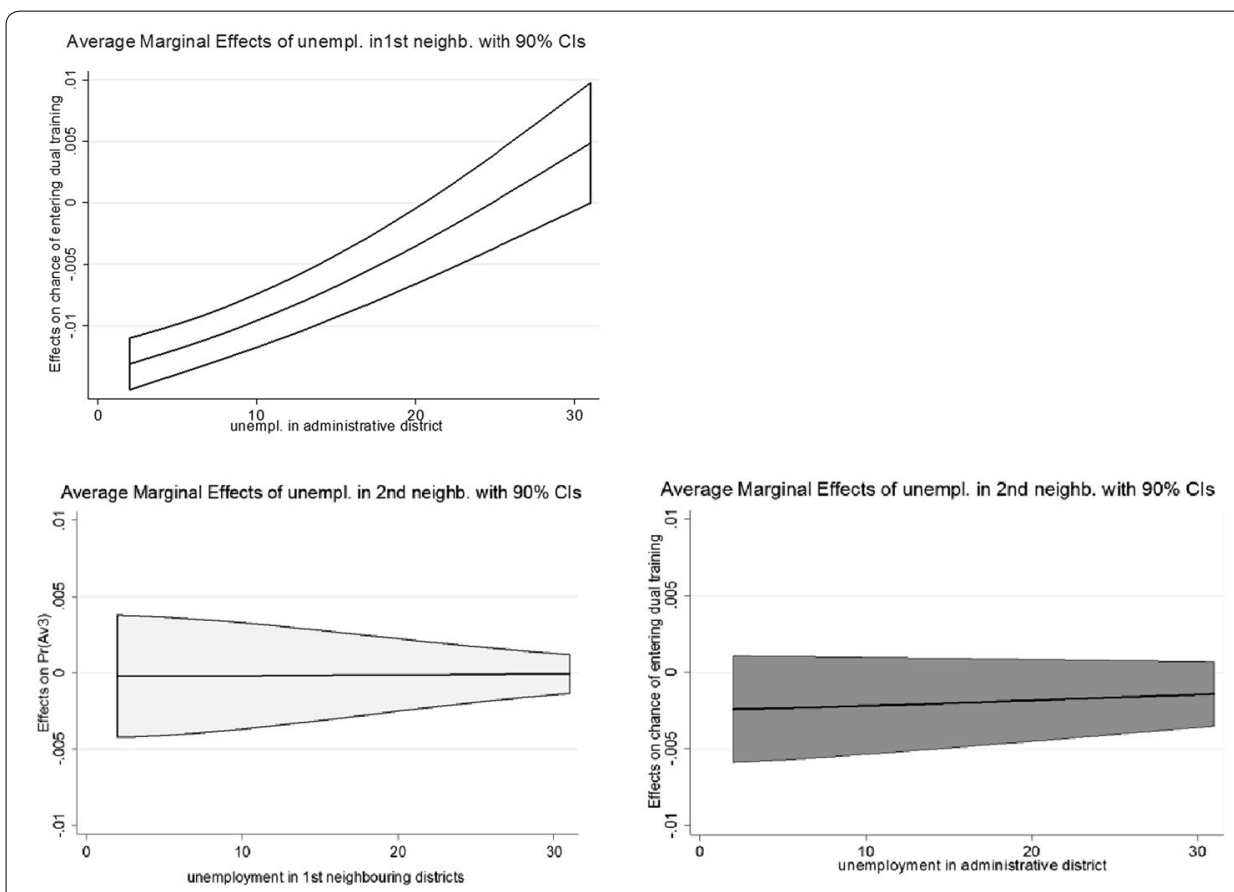

Fig. 5 AMEs (model 3) of unemployment rate in the 2nd neighbouring districts on the chance of entering dual training for specific values of unemployment rate in home district (left) and 1st neighbouring districts (right) (with 90 \%-Cls) Data: GSOEP, Federal Employment Office, Federal Statistical Office

the argument of status reproduction we find that chances are higher when parents have an intermediate school certificate and are at occupational qualification level. In our second hypothesis we argue that the impact of unemployment on the chance of obtaining a training position is not equal to these personal variables. Especially young adults with low or no school certificates are expected to be more strongly influenced by poor regional conditions. Model 4 includes interaction effects between unemployment rates and school leaving certificates.

As our results on the relevant spatial extension of the socio-economic context indicate that the second-order neighbouring districts have no impact on training chances, model 4 only focuses on home and first-order neighbouring districts. To illustrate the results we provided marginal effect plots for the three different types of school leavers-dropouts and graduates with lower or intermediate secondary degree-for specific values of unemployment in home and first neighbouring districts (see Fig. 6). Unemployment rates in the neighbouring districts especially interact with school leaving certificates. While graduates with lower secondary (Hauptschule) certificates experience decreasing chances with increasing unemployment in adjacent districts, intermediate (Realschule) graduates' relative chances to enter dual training increase with higher unemployment. The interaction between school certificates and the unemployment rate in the home district point in the same direction but are weaker. Contrary to our expectations we do not find these effects for dropouts. Potential explanations are that catching up on a school qualification is the most important educational alternative for dropouts and direct transitions to training are generally highly unlikely. Results could also be underestimated due 


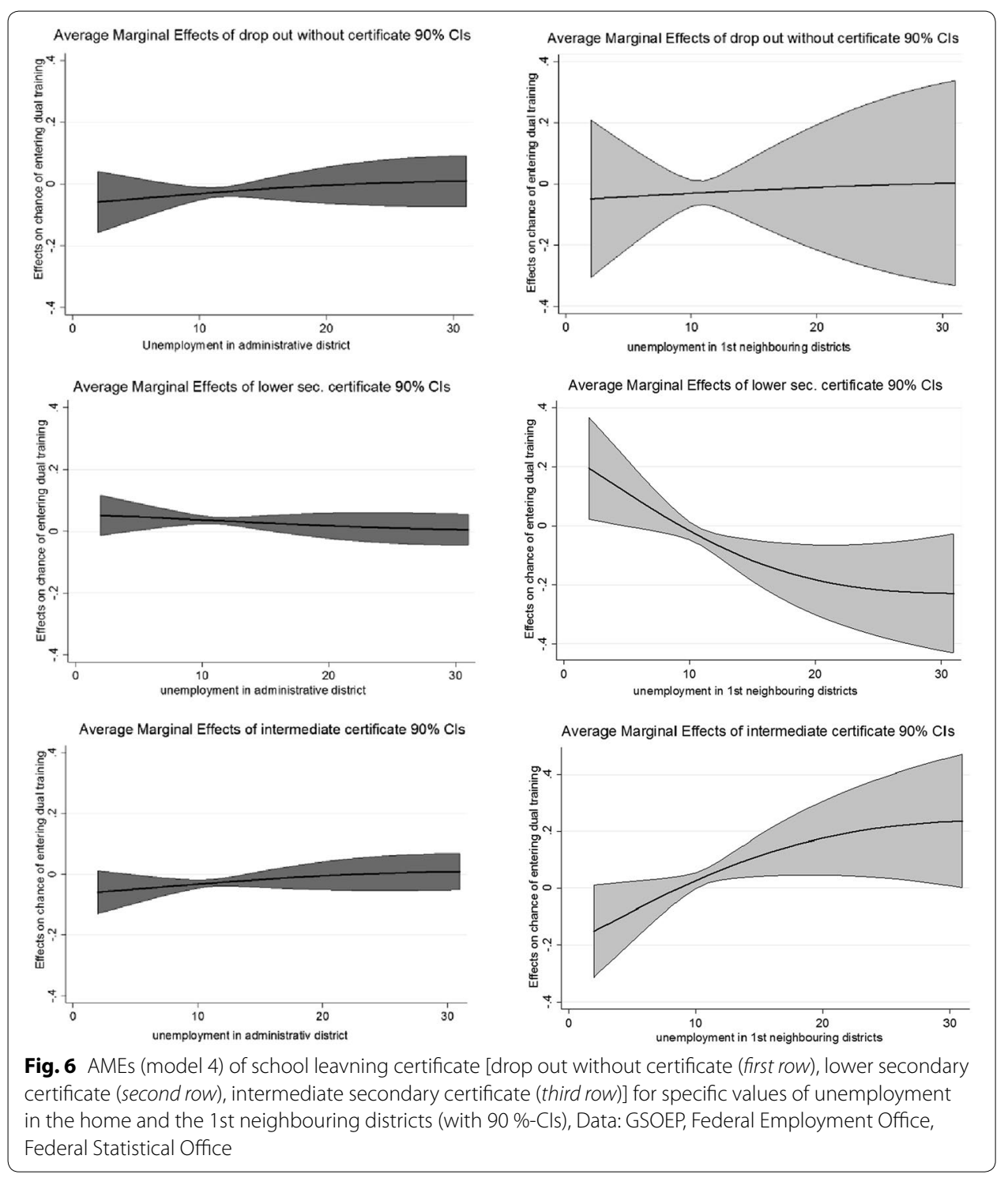

to the small number of cases in this category. As expected students with lower certificates are negatively influenced by high unemployment on regional level(s) and intermediate graduates have comparably better chances when unemployment is high. We argue that shortages in dual training opportunities are caused by poor economic conditions in the region that lead to increased competitive pressure for training positions. Lower qualified students are particularly affected by this.

\section{Conclusions}

On the basis of contiguity matrices, we calculated concentric rings of administrative districts to illustrate the contextual radius that impacts young adults' vocational training chances. We have applied this flexible concept of spatial modelling to analyse the impact of unemployment on transitions to dual training after lower and intermediate secondary schooling in Germany. In terms of the educational outcome we could show that it is 
not sufficient to only focus on the political districts where youngsters live in. Regional unemployment on several levels of aggregation-district and neighbouring districtshas a negative impact on the chance of entering the dual system. Our findings clearly suggest that it is promising to take the spatial structure of indicators that are assumed to influence individual life events into account. We find that fixed administrative units, e.g., the districts where the respondents live do not adequately represent the spatial context where unemployment effects on the transitions to training should be measured. The radius in which labour-market conditions influence training chances includes the home district as well as the directly adjacent districts. In contrast to this, the second-order neighbouring districts seem to be too remote to affect transition chances.

Moreover, the spatial units interact with one another; the higher the unemployment rate in the home district the lower the impact of unemployment in the surrounding districts. This finding can be interpreted as a reduction of the search radius when unemployment is high in the close-range area, which can be traced back to the discouragement of young adults in search for vocational training: Due to the poor economic situation in a region and the insufficient provision of training places school graduates' rather opt for educational and vocational alternatives (e.g., school-based training or further schooling), instead of extending their search radius. Also, we see that regional unemployment increases the competitive pressure among training applicants, which leads to lower chances for low-qualified graduates when unemployment on the regional level(s) is high.

Especially with respect to the fact that the transition to vocational training in the dual system is a two-folded process including both applicants' and employers' decisions, additional research steps should engage in disentangling the two sides of the decisionmaking process: It is known that the (regional) economic situation has an impact on employers' needs for apprentices. But rather than on the impact of contexts on employers' willingness to train, our focus is on the decision-making process of young school leavers and on the question of how and where contextual settings influence these decision and transition processes. It is argued that graduates' educational decisions-their evaluation of success probability, costs and benefits-are shaped in a rather closerange by peers, parents and neighbours etc. Moreover, the perception of labour-market chances is influenced by media coverage, which can be located in a rather wide spatial range. The provision of training places, on the other hand, is located in a commutable area. We argue that the two sides of the assumed effects point in the same direction and we can generally confirm that higher local unemployment leads to lower transition chances. Focusing on the impact of regional labour-market conditions on school graduates aspirations and wishes before the actual transition takes place is one way of separating supply- from demand-side effects. This would further explain the effect that contextual settings have on individuals' transitions to vocational training.

Another issue for future research is to analyse to what extent unemployment effects can be traced back to cyclical fluctuations rather than structural differences between regions. While controlling for the regional conditions we still find that the time in which a transition takes place influences training chances. This finding suggests that there are not only regionally effects but also temporally distributed effects of demand and supply. Moreover, direct effects of unemployment on individual transitions can be assumed 
to have greater relevance with the approaching individual labour-market entry. This implies that increased attention should be given to the consequences of labour-market conditions when studying the labour-market entry of young people finishing VET, also in terms of spatial patterns.

To conclude, the spatial reference of contextual characteristics is a relevant subject for sociological research that has so far received little attention. Our results implicate that research on the impact of contextual settings on individual life events should not be limited to a fixed structure of proximate contexts. It is of relevance to theoretically raise and discuss the question of where to locate a relevant contextual setting with respect to the theoretical mechanisms. It seems useful to empirically overcome spatial limitations of fixed aggregation units by introducing advanced spatial measurement techniques and adequate data sources. Practically, our results implicate that training advertisements and the allocation of supply and demand of training positions can and should not be limited to individual requirements and administrative structures but should instead be much more tailored to specific local situations.

\section{Additional files}

Additional file 1: Appendix Figure S1. Survivor function for different groups of school leavers (drop outs, lower secondary school graduates and intermediate secondary school graduates) to enter dual training within the first 3 years after school completion.

Additional file 2: Appendix Table S1. Frequency distribution and summary of independent variables on individual level, Data: GSOEP, 2012.

Authors' contributions

All authors read and approved the final manuscript.

\section{Acknowledgements}

We would like to thank the German Research Foundation (DFG) (Award No. 767/6-1) for project funding.

\section{Competing interests}

The authors declare that they have no competing interests.

Received: 19 August 2015 Accepted: 30 September 2015

Published online: 02 November 2015

\footnotetext{
References

Allison PD (1982) Discrete-time methods for the analysis of event histories. Sociol Methodol 13(1):61-98

Andersson EK, Malmberg B (2014) Contextual effects on educational attainment in individualised, scalable neighbourhoods: differences across gender and social class. Urban Stud. doi:10.1177/0042098014542487x

Anselin L (1995) Local Indicators of Spatial Association-LISA. Geogr Anal 27(2):93-115. doi:10.1111/j.1538-4632.1995 tb00338.x

Beicht U (2012) Berufswünsche und Erfolgschancen von Ausbildungsstellenbewerberinnen und -bewerbern mit Migrationshintergrund. Berufsbildung Wissenschaft und Praxis 6(12):44-48

Bernardi F, Requena Miguel (2010) Inequality in educational transitions: the case of post-compulsory education in Spain. Revista de Educación número extraordinario 2010:93-118

Betts JR, McFarland LL (1995) Safe port in a storm: the impact of labour market conditions on community college enrollment. J Hum Resour 30(4):741-765. doi:10.2307/146230

BMBF (2012) Berufsbildungsbericht 2012. Bonn: BMBF. http://www.bmbf.de/pub/bbb_2012.pdf

Bogai D, Seibert H, Wiethölter D (2008) Die Suche nach Lehrstellen macht junge Menschen mobil. IAB-Kurzbericht. Aktuelle Analysen und Kommentare aus dem Instut für Arbeitsmarkt- und Berufsforschung. 09/2008

Boudon R (1974) Education, opportunity, and social inequality: changing prospects in western society. Wiley, New York Breen R, Goldthorpe JH (1997) Explaining educational differentials: towards a formal rational action theory. Ration Soc 9(3):275-305. doi:10.1177/104346397009003002

Brunello G (2009) The effect of economic downturns on apprenticeships and initial workplace training: a review of the evidence. Empi Res Vocat Educ Train 1:145-171
} 
Card D, Lemieux T (2001) Can falling supply explain the rising return to college for younger men? A cohort-based analysis. Q J Econ 116(2):705-746

Carmeci G, Chies L (2002) Education and local labour market: the case of Italy. Working Paper DiSES 85, University of Trieste, Trieste

Clark D (2011) Do recessions keep students in school? The impact of youth unemployment on enrolment in post-compulsory education in England. Economica 78(311):523-545

Ditton H (2008) Schule und sozial-regionale Ungleichheit. In: Helsper W, Böhme J (eds) Handbuch der Schulforschung. VS Verlag für Sozialwissenschaften, Wiesbaden, pp 631-649. doi:10.1007/978-3-531-91095-6_25

Dobischat R (2010) Schulische Berufsausbildung im Gesamtsystem der beruflichen Bildung: Herausforderungen an der Übergangspassage von der Schule in den Beruf. In: Bosch G, Krone S, Langer D (eds) Das Berufsbildungssystem in Deutschland: Aktuelle Entwicklungen und Standpunkte. VS Verlag für Sozialwissenschaften, Wiesbaden, pp 101-131. doi:10.1007/978-3-531-92391-8_5

Drukker DM, Prucha IR, Raciborski R (2001) A command for estimating spatial-autoregressive models with spatial-autoregressive disturbances and additional endogenous variables. Stata J 13(2):287-301

Eckey HF, Schwengerl B, Türck M (2007) Vergleich von deutschen Arbeitsmarktregionen. IAB-Discussion Paper 2007 (3):1-23

Einig K, Pütz T (2007) Regionale Dynamik der Pendlergesellschaft: Entwicklung von Verflechtungsmustern und Pendeldistanzen. Informationen zur Raumentwicklung (2/3):73-91

Eirmbter WH (1977) Ökologische und strukturelle Aspekte der Bildungsbeteiligung. Beltz, Weinheim

Elhorst JP (2014) Spatial econometrics: from cross-sectional data to spatial panels. Springer, London

Esser H (1999) Soziologie. Spezielle Grundlagen (1): Situationslogik und Handeln. Frankfurt am Main: Campus, Frankfurt

Fotheringham AS, Wong DWS (1991) The modifiable areal unit problem in multivariate statistical analysis. Environ Plan 23(7):1025-1044

Gieryn TF (2000) A space for place in sociology. Annu Review Sociol 26:463-496

Grubb WN, Lazerson M (1982) Education and the labor market: recycling the youth problem. In: Kantor H, Tyack DB (eds) Work, youth, and schooling: historical perspectives on vocationalism in american education. Stanford University Press, Stanford, pp 110-141

Heineck G, Kleinert C, Vosseler A (2011) Regionale Typisierung: Was Ausbildungsmärkte vergleichbar macht. IAB-Kurzbericht 13/2011. Nürnberg: IAB. http://doku.iab.de/kurzber/2011/kb1311.pdf

Hillmert S (2001) Cohorts and competition: transitions from school to work in Germany in the context of economic and demographic change. Working Paper. Max Planck Institute for Human Development, Berlin

Hillmert S (2004) Soziale Ungleichheit im Bildungsverlauf: Zum Verhältnis von Bildungsinstitutionen und Entscheidungen. In: Becker R, Lauterbach W (eds) Bildung als Privileg: Erklärungen und Befunde zu den Ursachen der Bildungsungleichheit. VS Verlag für Sozialwissenschaften, Wiesbaden, pp 69-97

Hillmert S (2015) The importance of regions and the regions of importance. Conceptual problems of local context analyses. Working Paper. University of Tübingen, Tübingen

Hillmert S, Weßling K (2014) Soziale Ungleichheit beim Zugang zu berufsqualifizierender Ausbildung. Das Zusammenspiel von sozioökonomischem Hintergrund, Migrationsstatus und schulischer Vorbildung. Sozialer Fortschritt 4-5(2014):72-82

Hupka-Brunner S, Sacchi S, Stalder BE (2010) Social origin and access to upper secondary education in Switzerland: a comparison of company-based apprenticeship and exclusively school-based programmes. Schweizerische Zeitschrift für Soziologie 36(1):11-31

Kalter F (2006) Auf der Suche nach einer Erklärung für die spezifischen Arbeitsmarktnachteile von Jugendlichen türkischer Herkunft. Zeitschrift für Soziologie 35(2):144-160

Kauppinen TM (2008) Schools as mediators of neighbourhood effects on choice between vocational and academic tracks of secondary education in Helsinki. Eur Sociol Rev 24(3):379-391

Kleinert C, Jacob M (2012) Soziologische Bildungsforschung, Kölner Zeitschrift für Soziologie und Sozialpsychologie Sonderheft 52. In: Becker R, Solga H (eds) Strukturwandel des Übergangs in eine berufliche Ausbildung. Springer VS, Wiesbaden, pp 211-233. doi:10.1007/978-3-658-00120-9_9

Kwan MP (2012) The uncertain geographic context problem. Ann Assoc Am Geogr 102(5):958-968

Manning A, Petrongolo B (2013) How local are labor markets? Evidence from a spatial job search model. CEP Discussion Papers dp1 101, Centre for economic performance, London school of economics

Mare RD (1980) Social background and school continuation decisions. J Am Stat Assoc 75(370):295-305

Meschi E, JK Swaffield, A Vignoles (2011) The relative importance of local labour market conditions and pupil attainment on post-compulsory schooling decisions. IZA Discussion Papers 6143, Institute for the study of labor

Meulemann H, Weishaupt H (1976) Determinanten des Bildungsgefälles in Großstädten. In: D Bildungsrat (ed) Zur Standortplanung von Bildungseinrichtungen. Gutachten und Studien der Bildungskommission. pp 57-130

Micklewright J, Pearson M, Smith S (1990) Unemployment and early school leaving. Econ J 100(400):163-169. doi: $10.2307 / 2234193$

Mood C (2010) Logistic Regression: Why We cannot do what we think we can do, and what we can do about it. Eur Soc Rev 26(1):67-82. doi:10.1093/esr/jcp006

Muehlemann S, Wolter SC (2011) Firm-sponsored training and poaching externalities in regional labor markets. Reg Sci Urban Econ 41(6):560-570

Muehlemann S, Wolter SC, Wüest A (2009) Apprenticeship training and the business cycle. Empir Res Vocat Education Train 1(2):173-186

Müller W, Haun D (1994) Bildungsungleichheit im sozialen Wandel. Kölner Zeitschrift für Soziologie und Sozialpsychologie $46(1): 1-42$

Norton EC, Wang H, Ai C (2004) Computing interaction effects and standard errors in logit and probit models. Stata J 4(2):154-167

Peraita C, Pastor M (2000) The primary school dropout in Spain: the Influence of family background and labour market conditions. Educ Econ 8(2):157-168. doi:10.1080/096452900410721 
Pissarides C (1981) Staying on at school in England and Wales. Economica 48(192):345-363

Raffe D, Douglas Willms J (1989) Schooling the discouraged worker: local-labour market effects on educational participation. Sociology 23(4):559-581. doi:10.1177/0038038589023004004

Rice $P$ (1999) The impact of local labour markets in investment in further education: evidence from the England and Wales youth cohort studies. J Popul Econ 12(2):287-312

Rouwendal J (1999) Spatial job search and commuting distances. Reg Sci Urban Econ 29(4):491-517

Royston P (2013) Marginscontplot: plotting the marginal effects of continuous predictors. Stata J 13(3):510-527

Schupp J, Frühling M (2007) BIOAGE17: the youth questionnaire. In: Frick JR, Groh-Samberg O (eds) Biography and life history data in the German socio economic panel. DIW, Berlin, pp 159-163

Sforzi F (2012) Defining the spatial scale in modern regional analysis. In: Vázquez EF, Morollón FR (eds) From administrative spatial units to local labour market areas. Some remarks on the unit of investigation of regional economics with particular reference to the applied research in Italy. Springer, Heidelberg. doi:10.1007/978-3-642-31994-5

Statistisches Bundesamt (2013) Berufsbildung auf einen Blick. Statistisches Bundesamt, Wiesbaden

Tumino A (2013) The effect of local labour market conditions on educational choices: a cross country comparison. ImPRovE Discussion Paper No. 13/06, University of Antwerp

Ulrich JG (2013) Institutionelle Mechanismen der (Re-)Produktion von Ausbildungslosigkeit. In: Siebholz S, Schneider E, Busse S, Sandring S, Schippling A (eds) Prozesse sozialer Ungleichheit: Bildung im Diskurs. Springer VS, Wiesbaden, pp 93-106

Walters PB (1984) Occupational and labor market effects on secondary and post-secondary educational expansion in the United States: 1922-1979. Am Sociol Rev 49(5):659-671

Weller S (2008) Are labour markets necessarily, local'? Spatiality, segmentation and scale. Urban Stud 45(11):2203-2223 Weßling K, Wicht A (2015) Möglichkeiten der Nutzung regionaler Daten im Nationalen Bildungspanel—ein Überblick. NEPS Working Paper No. 54. Leibniz-Institut für Bildungsverläufe, Nationales Bildungspanel, Bamberg

Wolter S, Ryan P (2011) Apprenticeship. In: Hanushek EA, Machin S, Wößmann L (eds) Handbook of economics of education. Elsevier, Amsterdam, pp 521-576

Yamaguchi K (1991) Event history analysis. Sage, Newbury Park

\section{Submit your manuscript to a SpringerOpen ${ }^{\circ}$ journal and benefit from:}

- Convenient online submission

- Rigorous peer review

- Immediate publication on acceptance

- Open access: articles freely available online

- High visibility within the field

- Retaining the copyright to your article

Submit your next manuscript at $\mathbf{s p r i n g e r o p e n . c o m ~}$ 